\title{
Developing Massive Open Online Course (MOOC) : Need Analysis of Teaching Materials for Madrasah English Teachers
}

Dewi Wahyu Mustikasari

State Insitute for Islamic Studies (IAIN) of Salatiga

Email: dewi.w.mustikasari@gmail.com

DOI: 84http://dx.doi.org/10.18326/rgt.v10i2.170-184

\begin{abstract}
Submission
Track:

ENGLISH ABSTRACT

Received:

29-09-2017

The purposes of this study are (1) to recognize the textbooks or other

Final Revision: teaching materials used by the Madrasah English teachers, (2) to

25-11-2017 identify their obstacles in preparing the teaching materials, (3) to analyze the teaching materials which can be developed in MOOC, (4) to

Available online: analyze the teaching materials for MOOC which are related to the Indonesian curriculum, (5) to analyze their willingness of proffesional teaching development by joining MOOC. This study used a descriptive qualitative approach. Moreover, the subjects of the study were 3 English teachers of MTs Negeri Salatiga and 5 English teachers of MAN Salatiga. Observation, interview and documentation were used as the techniques of data collection. The results showed that (1) they used the textbooks from Ministry of Education (MOE), selected main handbooks, supplemenatary teaching materials from certain websites, (2) communicative competence as the main issue of content of textbook from MOE gave different challanges for them to prepare the teaching materials, (3) authentic materials were highly needed to be developed in MOOC, (4) characters building based-teaching materials needed to be developed too as those are the uniqueness of the Indonesian curriculum, (5) they had less interest to join MOOC as their way to develop their proffesional teaching development.
\end{abstract}

Keywords: MOOC, English teaching materials, authentic materials, characters building

\section{INDONESIAN ABSTRACT}

Tujuan penelitian ini adalah (1) untuk mengetahui buku-buku atau materi pelajaran yang digunakan oleh guru-guru Bahasa Inggris di madrasah, (2) untuk mengidentifikasi kendala yang dihadapi oleh 
mereka ketika menyiapkan materi pelajaran, (3) untuk meganalisa materi pelajaran yang dibutuhkan untuk mengembangkan MOOC, (4) untuk menganalisa materi pelajaran untuk MOOC yang sesuai dengan kurikulum di Indonesia, (5) untuk menganalisa kesanggupan guru-guru tersebut untuk mengikuti MOOC dalam usaha mereka untuk peningkatan mutu mengajar. Penelitian ini menggunakan pendeketan deskriptip kualitatif. Selanjutnya, subyek penelitiannya adalah 3 guru MTs Negeri Salatiga and 5 guru MAN Salatiga. Obeservasi, wawancara, dokumentasi digunakan sebagai teknik pegumpulan data. Hasil peneltian menunjukan bahwa (1) mereka menggunakan bukubuku dari Kemendikbud, buku-buku pilihan sekolah, materi tambahan dari situs, (2) kompetensi komuniksi sebagai isu utama dalam buku Kemedndikbud memberikan beberapa tantangan yang berbeda bagi mereka ketika menyiapkan mateeri pelajaran, (3) materi otentik sangat dibutuhkan untuk dikembangkan di MOOC, (4) pembelajaran berbasis karakter perlu dikembangkan juga sebagai keunikan kurikulum di Indonesia, (5) mereka memiliki kertetarikan yang rendah untuk mengikuti MOOC sebagai usaha untuk peningkatan mutu mengajar.

Kata kunci: $M O O C$, materi pelajaran Bahasa Inggris, materi otentik, pendidikan karakter

\section{INTRODUCTION}

Developing MOOC for Madrasah English teachers is designed to support their teaching professionalism. It is planned to be investigated in a multiyear study. In this paper, I propose to inform the first year study results which cover the need analysis of teaching materials for them. The term "need analysis" is "Procedures used to collect information about learners" needs are known as need analysis (Richards, 2001: 51)." The teaching materials which are analyzed must be related to the learners' needs. In addition, the teaching materials are essential to be discussed because Madrasah English teachers are mostly recognized to use text book. As it is informed by Liu \& Littlewood (1997) as mentioned by Zhenhui (2001) "Traditionally, the teaching of EFL in most East Asian countries is dominated by a teachercentered, book-centered, grammar-translation method and an emphasis on rote memory." The concept of teacher-based learning is commonly used by the Indonesian teachers, and text book is widely used by them, as it is obviously dominated the learning process. 
The classroom activities of the learning process need to be guided using textbook as the teaching material because based on Ansary and Babaii (2002) "a textbook is a framework which regulates and times the programs." Therefore, the Indonesian government also publishes the textbooks which are related to the curriculum. However, Lamie (1999) informs that "textbooks produced or approved by a governing body, such as a Ministry of Education (MOE), may purport to adhere to curriculum guidelines, but in reality not fulfill the objectives they set themselves." As a result, it is important to analyze the textbooks of MOE of Indonesia. Are they closely related to the needs of the teachers and students or not? Thinking about this point of view, thus, Allwright (1990) as quoted by Kitao and Kitao (1997:1) argues that "materials should teach students to learn, that they should be resource books for ideas and activities for instruction/learning, and that they should give teachers rationales for what they do. From Allwright's point of view, textbooks are too inflexible to be used directly as instructional material." It can be assumed that a good textbook is not a rescources pack which provides an intructional teaching materials because the teachers must recognize the students' needs in learning English. Unwise action is conducted by the teachers if they teach the students because they need to finish the teaching materials of the textbooks without recognizing the students'process of learning which expects them to perform communicative competence.

Boosting the students' communicative competence demands the teachers to use authentic materials so that the students are able to use English communicatively. The students can have an adequate competence if they can use anything in the real life situation as their stimulation to produce English in written or oral. As it is also claims by Kilickaya (2004) “Authentic material is significant since it increases students' motivation for learning, makes the learner be exposed to the real language as discussed by Guariento \& Morley (2001: 347)." The usage of authentic materials can motivate the students to be active in the classroom because they will use the real language, that is, English in reality not in an isolated situation. As it is also claimed by Kelly et.al (2005) "Providing authentic materials for language learning should be relied on students' need of using the language itself." If they need to be communicative in using English, thus, the teachers need to provide their demands. Moreover, authentic materials also can be gained from objects 
surrounds us, it is known as realia. Mumford (2005) informs that "we like using realia, i.e. objects in the class because it adds interest and relates language to the real world." The real object brings more realistic situation of life, thus, the students are able to produce daily used of English. Then, he finds three categories of using realia in teaching the students namely "first for descriptions, and second as props in drama and another type of activity is a creative thinking exercise, finding different uses for an object, e.g. a ruler could be a weapon, musical instrument, a symbol of authority and so on (Mumford, 2005)." His three main concept of beneficial realia can be adopted in the classroom so that the daily English can be made by the students. Realia is used to support the realization of real-life experiences. Brown (2001: 238) as stated by Mustikasari (2013: 169-170) "Experiential learning includes activities that engages both left and right-brain processing, that contextualize language, that integrate skills, and that point toward authentic, real-world purposes." Real-life experiences which resemble real-world activities occupy the students to use English by integrating the four skills, as it is described that English is not learned separately, but it is an integration of the skills. Listening and reading as the receptive skills are function as the former skills which are needed by the students when they create the productive skills that are writing and speaking. The students learn to contextualize English when they use the receptive and productive skills, thus, it acquires realia to help them to process an integration of language skills.

Critical thinking is another issue which must be provided in the learning process, except authentic material and integrated skills tasks. Fisher (2001:14) says that "Critical thinking clearly requires interpretation and evaluation of observation, communication, and other sources of information." Meanwhile, Cottrell (2005: 3) adds that "Critical thinking is associated with reasoning or with our capacity for rational thought. The word "rational" means using reasons to solve problems." Then, Norris and Ennis (1989: 3) as informed by Liaw (2007: 50) claim it "reasonable and reflective thinking that is focused upon deciding what to believe and do." It can be described that the students are clearly assumed to have an adequate knowledge to use their mental process to answer and do cognitive tasks in the learning process. Furthermore, they need to display their critical thinking quality of interpreting thought, classification, assortment, and decision. The critical thinking quality can be seen when students perform their self-regulation and learner autonomy to solve the problems. Tan (2003: 1) 'Problem solving in real-world contexts involves multiple ways of 
knowing and learning." Thus, by activating the critical thinking, it is hoped that the students are able to use various steps of knowing and learning in term of problem solving. In addition, they need the teachers to guide them. As it is stated by Tan (2004: 2) calls "The role of the teacher is to enable students to recognize the state, repertoire, and depth of various dimensions of their thinking and to sharpen their abilities to deal with real-world problems." Having the teachers' guidance, the students can maximize their scope of thinking.

The authentic material, integrated skills tasks and critical thinking are hoped to equip the students to gain communicative competence. Therefore, the teachers must have teaching strategies to be used to boost the students' communicative competence, thus, the teachers must consider their own teaching professionalism. In this occasion, I like to introduce MOOC as an alternative domain for them to increase their teaching professionalism. Then, what is MOOC? The following paragraphs answer this question.

Ozturk (2015) states that "Ideas of Open Educational Resources Movement (OERM) advocating for free access to resources for learning, teaching, and research (Knox, 2013) underpinned the pedagogical design of MOOCs." This term makes education as a turning point of expensive and unacssessable schools. It can not be denied that digital era brings positive movements to educate everyone. Thus, it is possible to provide free access for open resources.

As one of the mode of open recources, MOOC is a platfrom to develop an on-line course with a huge number of students. Andersen and Ponti (2014) as it is quoted by Ozturk (2015) mentions "MOOCs as structured and organized OER in the form of a course with participation from educators or organizers." A structured-course of MOOC is easily developed because there are some providers that offer various platforms which can be found in the internet. Class2go, eliademy, and mooc.org (some of providers) provide a free MOOC platforms. Agarwalt (2013) claims that "Many organizations are offering these online courses to students all over the world, in the millions, for free. Anybody who has an Internet connection and the will to learn can access these great courses from excellent universities and 
get a credential at the end of it." Thus, it can be inferred that MOOC provides advantages for learners who have willingness to learn and want to develop their knowledges as long as they have internet connection. In addition, they do not have to pay the tuition fee because it is free. As it is also stated by Jordan (2014), Liyanagunawardena, Adams, \& Williams (2013) as mentioned by Israel (2015: 102) "MOOCs are online courses open to all who have access to an internet connection and are self-motivated in learning anywhere and anytime in the world."

The benificials of MOOC are those mentioned above. This new invention of learning triggers some researchers to conduct various researches on MOOC. Firstly, Mackey and Evans (2011) found that the respondents (15 professional teachers who were taken their Graduate Diploma in ICT in Education at the University of Canterbury) took control of their own on-line learning experiences by (1) freely choosing the level of interaction in online and off-line communication, (2) connecting the theorical framework and practical application from the coursework to their work athmosphere. However, they were not interested to have a permanent relationship with the others in the on-line athmospheres bacause they just needed to take the advantages of the on-line learning. Secondly, Kop (2011) informed that the respondents performed their participation in joining the MOOC by aggregating, relating, and sharing resources. On the contrary, they showed less active in creating the digital artefacts namely blog posts and video.

From the above previous researches it can be analyzed that the respondents seek for knowledges for their proffesionalism in their own work contexts, thus, it can inferred that Madrasah English teachers also can be facilitated to have this such enviroment of learning for their proffesional teaching development. Clarà \& Barberà (2013) in Comer, Clark, and Canelas (2014: 27-28) state that "MOOCs, because of their scale, offer a significant opportunity for peer-to-peer interaction in the form of dialogic, networked learning experience." Independent learning demmand to be conducted by them because joining MOOC will need some efforts. They have to manage their times wisely because some courses will require them to do reading session and submitting tasks. Some MOOCs provide group discussion which useful for the member to have a discussion on the reading session. In addtion, they also capable to inform and share their problems related to technical matters. 
Designing MOOC for Madrasah English teachers becomes important to support their proffesionalism in teaching. Eventhough, in reality it can be easily enough to find MOOCs of english courses, but those MOOCs do not consider the Indonesian curriculum. They provide food of thought about english language teaching, but they do not directly organize the Indonesian curriculum which explores the usage of characters building in the teaching and learning process. Thus, creating MOOC which includes the characters building will support the Indonesian government to widesprade the knowledge of integrating the characters building into the classroom activities.

\section{METHODOLOGY}

I used descriptive qualitative research and conducted some following steps namely organizing, explaining, categorizing and classifing the data of the Madrasah English Teachers' needs in preparing the teaching material, and using it while teaching the students, in order to define the teaching materials for Madrasah English Teachers which can be used to develop MOOC and recognized the teaching materials which is related to Indonesian curriculum.

The subjects of study were three teachers from MTs Salatiga, and four teachers from MAN Salatiga. Those Madrasah English teachers had more than 5 years of teaching experiences and got their proffesional teaching certification. Furthermore, they had the experiences of several different Indonesian curriculums when they have been taught the students.

The research was conducted in the first semester in the academic year of 2015/2016. The data were started to be collected from July until September 2015.

The techniques of data collection in this research were observation (field notes), documentation (the textbooks from Ministry of Education (MOE), selected main handbooks, supplemenatary teaching materials from certain websites) and interview (a semistuctured interview).

\section{RESULTS}

Textbooks or Other Teaching Materials Used By the Madrasah English Teachers 
It was recognized that most of them used three types of teaching materials namely the textbooks from Ministry of Education (MOE), selected main handbooks, supplemenatary teaching materials from certain websites.

The textbooks from MOE were extremely good to be used as a teacher and student book. Although, those books did not mention the guideline of how to use the book, but those books easily can be used and covered various activities to engange the students. For example the activities of one chapter of the textbook for the ten graders of senior high schools/ madrasah as follow:

1. Warmer (game: Chinese Wishper)

2. Vocabulary builder

3. Pronounciation practise

4. Reading (Jigsaw)

5. Vocabulary exercises

6. Text structure (Think-pair-share)

7. Grammar review

8. Speaking (Guessing game: Ball trawing)

9. Writing

10. Reflection

Most of the textbooks of MOE supplied four skills (reading, listening, speaking, and writing skills) which were hoped to be activated by the students because they needed to perform their communicative competence as the targeted-indicators which were also mentioned in the textbooks. Furthermore, the teachers was hoped to play role as facilitator. The reflection part was a good space for the students to washback their abilities whether they were able to achieve the indicators of each chapter or not. Some of textbooks also provided motivating words which came from famous people, eventhough, those motivating words did not appear in each chapter.

Table 1. Motivating Words

\begin{tabular}{|l|l|l|l|}
\hline No & $\begin{array}{l}\text { Topic of the } \\
\text { cahapter }\end{array}$ & Motivating Words & Page \\
\hline 1 & $\begin{array}{l}\text { Talking about } \\
\text { Self }\end{array}$ & $\begin{array}{l}\text { Accept responsibility for your life. Know that is you who } \\
\text { will get you where you want to go, no one else (Les Brown) }\end{array}$ & 16 \\
\hline 2 & Complimenting & The only thing that stands between you and your dream is the & 30 \\
\hline
\end{tabular}




\begin{tabular}{|c|c|c|c|}
\hline & $\begin{array}{l}\text { and Showing } \\
\text { Care }\end{array}$ & $\begin{array}{l}\text { will to try and the belief that is actually possible (Joel } \\
\text { Brown) }\end{array}$ & \\
\hline 3 & $\begin{array}{l}\text { Expressing } \\
\text { Intension }\end{array}$ & $\begin{array}{l}\text { The only way to do great work is to love what you do. If you } \\
\text { haven't found it yet, keep looking. Don't settle (Steve Job) }\end{array}$ & 42 \\
\hline 4 & $\begin{array}{l}\text { Congratulating } \\
\text { Others }\end{array}$ & - & - \\
\hline 5 & $\begin{array}{l}\text { Describing } \\
\text { People }\end{array}$ & Life is either a daring adventure or noting (Hellen Keller) & 66 \\
\hline 6 & $\begin{array}{l}\text { Visiting } \\
\text { Ecotourism } \\
\text { Destination }\end{array}$ & $\begin{array}{l}\text { A journey of a thousand miles begins with a single step (Lao } \\
\text { Tzu }\end{array}$ & 80 \\
\hline 7 & $\begin{array}{l}\text { Visiting } \\
\text { Niagara Falls }\end{array}$ & - & - \\
\hline 8 & $\begin{array}{l}\text { Describing } \\
\text { Historical } \\
\text { Places }\end{array}$ & - & - \\
\hline 9 & $\begin{array}{l}\text { Giving } \\
\text { Announcement }\end{array}$ & - & - \\
\hline
\end{tabular}

Source: MOE textbook for the ten graders of senior high schools/ madrasah

It was nice to discover that the textbooks clearly display character traits into the topics in order to boost the students' awareness of character buildings by giving the motivating words. However, the famous people should be introduced. Who are they? Why their motivating words must be recognized by them? What is so special about those famous people? From the above explanation about the textbooks of MOE, it can be informed that the textbooks were highly designed to shape the students' communicative competence, but the textbooks were used as a secondary book by the Madrasah English teachers, and the students may borrow the textbooks in the library so the targeted-competence was not achieve properly because they did not use the textbooks of MOE.

On the other hand, the selected books were choosen by the Madrasah English teacher as the main book to be used by them and the students. The MAN Salatiga English teachers discussed and decided one book to be used as the main book for all classes, eventhough, the students joined different classes which were taught by different teachers, they had the same learning activities because they used the same book. On the contrary, the MTs English teachers had different preferance to choose the main book. The students still got the same content of the topic of discussions, eventhough, they taught the students using different books, 
but they strickly chose the main books which were related to the syllabus. One of the example of the selected books was english book for the ten graders of senior high schools/ madrasah which is publised by Intan Pariwara. The book implemented the syllabus, and it included tasks, assessments, mid-term test, and final test. In addition, it had a homework which was connected to the internet. The tasks were a series of activities such as warmer, vocabulary builder, pronounciation drills, reading text, and grammar focus. Furthermore, the book also provided a guideline of how to use the book and motivating words. However, the selected books did not provide the integrated tasks skills to foster the students' communicative competence because the series of task or assessment were done by them as a routine activity in the classroom, and English was in an isolated situation.

The next teaching material was selected websites. Few of the Madrsah English (the advance one who had willingness to use internet) used the selected websites to find pictures, photographs, diagrams, songs and videos for grammar focus or other related topics. Using internet was an optional action to do, if they found that the activities using the selected books were various they were not consider finding authentic materials in the internet.

\section{Obstacles in Preparing the Teaching Materials}

Challaging situation were faced by the Madrasah English teachers in preparing the teaching materials due to the need to facilitate the students to perform their communicative competence as the main issue of content of textbooks of MOE. Firsly, most of them complaint that the students did not have an adequate four skills of learning english so they can not be forced to perform the communicative competence by using the textbooks of MOE. They informed that the students needed to be stimulated to be an active student in a class, and it can not be done by using the textbooks of MOE. Secondly, the students' confidanceness to learn english was another issue which needed to overcome. Thirdly, there was a lack of supply of the textbooks of MOE. Therefore, the students can not get those books, but they may borrow those books in the library. Thus, those books were not use as the main book. Fourthly, they needed to discuss, think and choose only one book as the main selected book. This is a hard situation to be handle because each teacher had different perspective. 


\section{Teaching Materials which can be Developed in MOOC}

To foster the students' communicative competence, the Madrasah English teachers must be supplied with authentic materials. It informed that selected books were dominated the programs, but it provides less space for the students to perform communicative competence because they got less vocabulary building. The authentic materials that can be given daily words of english which is occured in printed text, realia, images and multimedia. Those authentic materials must be easily found in the real-life situation because those items are real things in the real world. In addition, the authentic materials must be cheap and easily to be prepared by the Madrasah English teachers and students. They can collaborate to prepare the authentic materials with the students. Thus learning english is not in isolated world that is in a classroom. It is hoped that it can be used to activated the students' communicative competence.

\section{Teaching Materials for MOOC Which Are Related to the Indonesian Curriculum}

The characters building based-teaching materials highly needed to be developed in the MOOC because it is the uniqueness of the Indonesian curriculum. The motivating words which were existed in the textbooks of MOE or selected books should not be only read and understood by the students. Thus, it was just a lip service because the students only understood the context of the motivating words literaly. It is going to be useless if there is no action after they understand those motivating words. They need to be guided to take the action. Therefore, the concept of characters building based-teaching materials can be used to help the students to perform the character traits. In addition, the characters building based teaching materials is done by providing the students with authentic materials and asking them to perform their communicative competence which includes their performance of character traits. For example, the character trait of confidance "belief in your self you can do it," when they want to introduce them self is hard to be done if the students have less vocabulary and they tend to copypaste the model of how to introduce your self in the textbooks. Therefore, the teachers ask the students to tell about their hobbies and bring one of their favorite items which resembles it, then stimulate them to tell (not reading the script) it in front of the classroom. Their favorite items are authentic materials (realia). Furthermore, the teachers can ask them to prepare the realia at home. Telling about themselve is going to be interesting to be 
followed by the entire members of the class because they bring different realia. On the other hand, the characters building based-teaching material also can be conducted by providing the students with various Islamic stories and events as the reading texts. From the data, it was revealed that the reading texts of the textbooks of MOE and selected books rarely display the Islamic stories or events. Thus, it is not a bad ideas to integrate the Islamic point of view of characters building in the concept of chaaracters building based-teaching materials.

\section{Willingness of Proffesional Teaching Development by Joining MOOC}

Most of the Madrasah English teachers admit that they have difficulty to join the MOOC because of their personal matters such as office duty and home affairs. Thus their less intension to be a part of the project results in some considerations to be jotted down in creating the MOOC namely

1. Avoid a time consuming design of activities for the MOOC

2. Work with the English teacher association to support the project

3. Invite more respondents in the project such as novice teachers who teach English in Madrasah or other private Islamic schools

4. Work with colleagues to be a part of the project by asking their students to join the MOOC because later on the students will have to conduct the intership program.

The noval result exposed that the characters building based-teaching materials must be designed and developed to maximize the usage of authentic materials, integrated-skills tasks, and critical thinking in order to boost the students' communicative competence. Those items can be listed in developing the MOOC.

Another essential finding covered that the textbooks of MOE were not meet the expectation of fostering the students' communicative competence because the textbooks were not used as the main book for some reasons. Firstly, there was less supply of the textbooks in the schools, although the textbooks also had the pdf version but not all of the students had 
laptop to open it, and using technology in the classroom was not easy to be organized by the teachers. Secondly, the teachers argued that the textbooks were not suitable to be used as the main book because the students were not ready to perform the activities in the textbooks because of the students' inadequate English skills and confident. As a result, the findings of the research support Lamie's theory in 1999. According to him, the government fails to provide a well-designed textbook which is related to the curriculum requirements, but in fact, it is not sufficient to support the academic goals of learning.

\section{CONCLUSION}

In conclusion, to develop a MOOC for them quite challenges because certain things need to be adjusted so that they are able to join this MOOC for their professional development. Furthermore, the teaching materials which supply them with real-world activities can be provided by using authentic materials as the media of teaching. In addition, it is essential to provide the teaching materials which are related to the Indonesia curriculum and needed to improve the students' cognitive competence.

\section{REFERENCES}

Agarwal, Anant. (2013). Why Massive Open Online Courses (still) Matter. Retrived from http://www.ted.com/talks/anant_agarwal_why_massively_open_online_courses_still_matter on 27 May 2014

Ansary, Hasan and Babaii, Esmat. 2002. Universal Characteristics of EFL/ESL Textbooks: A Step Towards Systematic Textbook Evaluation. The Internet TESL Journal, Vol. VIII, No. 2, February 2002. http://iteslj.org/Articles/Ansary-Textbooks/ 21/09/15 
Comer, Denise K., Clark, Charlotte R and. Canelas, Dorian A. 2014. Writing to Learn and Learning to Write across the Disciplines: Peer-to-Peer Writing in Introductory-Level MOOCs. International Review of Research in Open and Distributed Learning. Volume 15, Number 5 November 2014

Cottrell, Stella. 2005. Critical Thinking Skills-Developing Effective Analysis and Argument. New York: Palgrave Macmillan

Fisher, Alec. 2001. Critical Thinking-An Introduction. Cambridge: Cambridge University Press.

Israel, Maria Joseph. 2015. Effectiveness of Integrating MOOCs in Traditional Classrooms for Undergraduate Students. International Review of Research in Open and Distributed Learning. Volume 16, Number 5 September - 2015.

Kelly, Charles., Kelly, Lawrence., Offner, Mark and Vorland, Bruce. 2005. Effective Ways to Use Authentic Materials with ESL/EFL Students. The Internet TESL Journal, Vol. XI, No. 2, February 2005. http://iteslj.org/Techniques/Mumford-Relia.html.21/09/15

Kilickaya, Ferit. 2004. Authentic Materials and Cultural Content in EFL Classrooms. The Internet TESL Journal, Vol. X, No. 7, July 2004. http://iteslj.org/Techniques/KilickayaAutenticMaterial.html. 21/09/15

Kitao, Kenji and Kitao, S. Kathleen. 1997. Selecting and Developing Teaching/Learning Materials. The Internet TESL Journal, Vol. IV, No. 4, April 1997. http://iteslj.org/Articles/Kitao-Materials.html.21/09/15. 21/09/15

Kop, Rita. 2011. The Challenges to Connectivist Learning on Open Online Networks: Learning Experiences during a Massive Open Online Course. International Review of Research in Open and Distance Learning Vol. 12.3 March-2011.

Lamie, Judith M. 1999. Making the Textbook More Communicative. The Internet TESL Journal, Vol. V, No. 1, January 1999. http://iteslj.org/Articles/LamieTextbooks.html.21/09/15

Liaw, Meei-Ling. 2007. Content-Based Reading and Writing for Critical Thinking Skills in an EFL Context. English Teaching \& Learning 31.2 (Summer 2007): 45-87

Mackey, Julie and Evans, Terry. 2011. Interconnecting Networks of Practice for Professional Learning. International Review of Research in Open and Distance Learning Vol. 12.3 March-2011. 
REGISTER JOURNAL

Vol. 10, No. 2, 2017, pp.170-184

p-ISSN: $1979-8903$; e-ISSN : 2503-040X

Mumford, Simon. 2005. Using Creative Thinking to Find New Uses for Realia. The Internet TESL Journal, Vol. XI, No. 2, February 2005. http://iteslj.org/Techniques/Mumford-Relia.html. 21/09/15

Mustikasari, Dewi Wahyu. 2013. Real-Life Activities: Boosting my students' awareness of Honesty in Creating Genre, $2^{\text {nd }}$ English Language Teaching Literature and Translation International Conference Proceedings, pp. 168-176

Ozturk, Hayriye Tugba. 2015. Examining Value Change in MOOCs in the Scope of Connectivism and Open Educational Resources Movement. International Review of Research in Open and Distributed Learning Volume 16, Number 5 September 2015

Richards, Jack. C. 2001. Curriculum Development in Language Teaching. Cambridge: Cambridge University Press.

Tan, Oon-Seng. 2003. Problem-Based Learning Innovation: Using Problems to Power Learning in the 21st Century. Singapore: Gale Cengage Learning

Tan, Oon-Seng. 2004. Cognition, Metacognition, and Problem-based Learning. Enhancing Thinking Through Problem-Based Learning Approaches: International Perspectives (Ed. Tan). Singapore: Gale Cengage Learning

Zhenhui, Rao. 2001. Matching Teaching Styles with Learning Styles in East Asian Contexts. The Internet TESL Journal, Vol. VII, No. 7, July 2001. http://iteslj.org/Techniques/Zhenhui-TeachingStyles.html. 21/09/15 